\title{
Waardebepaling en waarderingsmethoden
}

\section{Dr. W.G.M. Holterman}

\section{Inleiding}

Het vraagstuk van de waardering van aandelen geniet, getuige de niet aflatende stroom publikaties over dit onderwerp, een grote belangstelling. Een belangrijk thema in dit verband is de keuze van de te hanteren waarderingsmethoden. De populariteit van boeken als Creating Shareholder Value (Rappaport 1986) en Valuation (Copeland e.a 1990) wijst erop dat de aan de financieel-economische theorie ontleende 'discounted cash flow'-methode (DCF-methode) in de praktijk in opmars is. Zoals onder meer blijkt uit door praktici gehanteerde handboeken en verslagen inzake feitelijke overnames worden in de praktijk ook verschillende andere waarderingsmethoden gebruikt, zoals de intrinsieke waarde, koers/ winst-verhoudingen en de rentabiliteitsmethode. $\mathrm{Er}$ is tot op heden nauwelijks wetenschappelijk onderzoek verricht naar de wijze waarop de waardebepaling in de praktijk geschiedt, hetgeen niet in de laatste plaats wordt veroorzaakt door het feit dat het besluitvormingsproces rondom de waardebepaling door de betrokken partijen als uiterst vertrouwelijk wordt ervaren en vaak niet naar buiten wordt gebracht. DeAngelo (1990) is naar ons weten het enige systematische onderzoek naar het gebruik van waarderingsmethoden in de praktijk. Zij constateert op basis van een onderzoek naar door Amerikaanse investment bankers gehanteerde waarderingsmethoden dat deze bij waardebepalingen gebruik maken van verschillende methoden - 'generally accepted valuation techniques' - en dat de DCF-methode in de besluitvorming niet het gewicht krijgt dat op grond van de financieel- economische theorie verwacht zou kunnen worden.

De geconstateerde leemte in het empirisch onderzoek naar de waardebepaling van aandelen was voor mij aanleiding dit onderwerp centraal te stellen in mijn dissertatie (Holterman, 1993). Het proefschrift heeft betrekking op niet ter beurze genoteerde ondernemingen en bevat een theoretisch en een empirisch gedeelte.

Het theoretische deel richt zich op de bruikbaarheid van inzichten uit de financiële economie bij de waardering van niet genoteerde aandelen. Er bestaan tal van verschillen tussen ter beurze en niet ter beurze genoteerde aandelen, men denke bijvoorbeeld aan de zeggenschap die aandeelhouders kunnen uitoefenen, de rechtsvorm van de onderneming en de courantheid van de aandelen. De financiële economie richt zich bij de modellering van waarde in eerste instantie op ter beurze genoteerde aandelen. Effectenbeurzen vormen bij uitstek de empirische benadering van de in de theorie vigerende perfecte en efficiënte markten. Wat zijn de implicaties van het ontbreken van een beursnotering? Deze vraag wordt in de dissertatie in twee stappen beantwoord. De eerste stap is gericht op het begrijpen van de verschilien tussen genoteerde en niet genoteerde ondernemingen. Zo komt onder meer de relatie tussen ondernemingsomvang, rechtsvorm en beursnotering aan de orde. Op grond van deze analyse kunnen di-

Dr. W.G.M. Holterman, registeraccountant, studeerde bedrijfseconomie en accountancy aan de Rijksuniversiteit Groningen (RuG). Tot 1 oktober 1994 was hij universitair docent Financieel management aan de Faculteit der Economische Wetenschappen van de RuG. Vanaf die datum is hij werkzaam bij Coopers \& Lybrand Corporate Finance te Amstelveen. 


\section{MAB}

verse kenmerken van niet genoteerde ondernemingen geduid worden, zoals de rol van zeggenschap, de economische betekenis van de rechtsvorm, de functie van de blokkeringsregeling bij BV's en de aard van de onderlinge relatie tussen aandeelhouders in de BV. Bij de analyse wordt gebruik gemaakt van inzichten uit de agency- en de transactiekostentheorie. In de tweede stap worden de gevolgen van het ontbreken van een beursnotering uitgedrukt in termen van ontbreken van de functies die een perfecte en efficiënte markt vervult. Zo kan de incourantheid van niet genoteerde aandelen opgevat worden als een belemmering die aandeelhouders ondervinden in hun mogelijkheden tot consumptie- en risicospreiding.

Het empirische onderzoek richt zich op de beschrijving en verklaring van de gehanteerde waardebegrippen en waarderingsmethoden en op de rol die deze spelen in het besluitvormingsproces rondom een transactie. In het onderzoek speelt de analyse van de betekenis en functie van de waardebepaling een belangrijke rol. Het onderzoek is exploratief van aard en geschied aan de hand van zes case studies. Gezien het exploratieve karakter van de studie is gekozen voor uiteenlopende waarderingssituaties. Drie cases hebben betrekking op de waardebepaling van een onderneming in het kader van een overname. De overige drie cases hebben betrekking op waardebepalingen onder de werking van een statutaire blokkeringsregeling in BV's.

Dit artikel is beperkt tot één aspect van het proefschrift: de beschrijving en verklaring van de in de overname-cases gehanteerde waarderingsmethoden. De verdere opzet van dit artikel is als volgt. Paragraaf 2 bevat een beknopt overzicht van in de praktijk gehanteerde waarderingsmethoden. In paragraaf 3 wordt de waardebepaling in de context van het overnameproces geplaatst. Paragraaf 4 geeft een overzicht van de belangrijkste onderzoeksbevindingen. In de paragrafen 5 en 6 worden verklaringen gegeven voor de in de cases gehanteerde waarderingsmethoden.

\section{Een overzicht van waarderingsmethoden}

In de case studies worden door de betrokkenen verschillende waarderingsmethoden gehanteerd. In de inleiding werden reeds de DCF-methode, koers/winst-verhoudingen en de rentabiliteitsmethode genoemd. Met het oog op een nadere ordening van methoden is het onderscheid tussen waardebegrippen en waarderingsmethoden van belang. Van Dale (1992, p. 1866) definieert een waardebegrip als een 'denkbeeld over de bepaling van waarde'. Een dergelijk denkbeeld kan bijvoorbeeld gebaseerd zijn op normen, theorieën of modellen. Een waarderingsmethode kan aangemerkt worden als een manier om de in het begrip vervatte waarde te bepalen. Van Dale (1992, p.1866) definieert een methode als: 'een vaste, weldoordachte manier van handelen om een bepaald doel te bereiken'. Er bestaat dus een hiërarchische relatie tussen waardebegrippen en waarderingsmethoden.

In het kader van de waardering van aandelen zijn twee waardebegrippen van belang: het financieel-economische waardebegrip en het waardebegrip uit de financiële accounting. Voor de waardebepaling van ondernemingen in het kader van transacties ligt het gebruik van het financieel-economische waardebegrip het meest voor de hand, immers dit waardebegrip specificeert de waarde van (aandelen van) ondernemingen op de vermogensmarkt. Het financieel-economische waardebegrip is prospectief gericht: een contante waarde van toekomstige kasstromen.

Tegenover het financieel-economische waardebegrip kan het waardebegrip uit de financiële accounting, belichaamd in de intrinsieke waarde, gesteld worden. Dit waardebegrip hangt nauw samen met de winstbepaling van ondernemingen. Als uitvloeisel van het 'matching principle' worden kosten van aangeschafte produktiemiddelen toegerekend aan de met behulp van het realisatiecriterium bepaalde omzet. Voor zover de gemaakte kosten betrekking hebben op de omzet in toekomstige jaren, worden deze in overeenstemming 
met het 'matching principle' geactiveerd op de balans. Deze niet gealloceerde kosten, de boekwaarde van de activa, vormen een belangrijke component van de intrinsieke waarde. Uit deze beschrijving blijkt dat het waardebegrip uit de financiële accounting retrospectief georiënteerd is.

In tabel 1 (zie pagina 606) zijn de belangrijk ste in de praktijk gehanteerde waarderingsmethoden ingedeeld in de volgende drie categorieën: ${ }^{1,2}$

A Methoden waarbij via discontering de contante waarde bepaald wordt.

$\mathrm{B}$ De intrinsieke waarde, gebaseerd op het waardebegrip uit de financiële accounting

C Methoden waarbij de waarde van ondernemingen via verhoudingsgetallen wordt ontleend aan de prijs (beurskoers c.q. overnameprijs) van vergelijkbare ondernemingen.

De methoden in categorie A kunnen geclassificeerd worden onder het financieel-economische waardebegrip. Behalve de DCF-methode bevat deze categorie enkele in de praktijk gebezigde methoden die theoretisch bezien als minder juist beschouwd kunnen worden Zo worden bij de zogenaamde rentabiliteitsmethode en de goodwill-methode winsten gedisconteerd, terwijl de financieel-economische waarde een contante waarde van kasstromen is. De methoden onder C zijn niet op voorhand onder de hiervoor genoemde waardebegrippen te classificeren. In tegenstelling tot de methoden onder $A$ en $B$ vindt bij de methoden onder $\mathrm{C}$ geen zelfstandige reconstructie van de waarde plaats; de waarde wordt ontleend aan de prijzen van vergelijkbare ondernemingen. In paragraaf 5.2 zullen de methoden onder $\mathrm{C}$ geïnterpreteerd worden vanuit het financieel-economische waardebegrip.

\section{Waardebepaling en overnameproces}

Het proefschrift bevat drie aan de praktijk ontleende, geanonimiseerde cases inzake de waardering van een onderneming in het ka- der van een overname. Het onderzoek is verricht bij een organisatie van fusie- en overname-adviseurs die van cliënten de opdracht krijgt de waarde van hun onderneming te bepalen. De cases worden gevolgd vanuit het perspectief van de adviseurs. De cases hebben betrekking op de verkoop van een adviesbureau, de verkoop van een metaalbedrijf en de koop van een grondstoffenproducent.

De waardebepaling van een onderneming geschiedt niet op één bepaald moment. Het vraagstuk van de waardebepaling strekt zich uit over verschillende fasen van het overnameproces: vanaf het eerste contact tussen de koper en de verkoper tot en met de onderhandelingen. In de dissertatie worden de volgende fasen onderscheiden: ${ }^{3}$

1 de zoekfase, waarin gericht wordt gezocht naar kandidaten die voldoen aan het acquisitieprofiel;

2 het vooronderzoek, waarin het eerste contact gelegd wordt en waarin afspraken worden gemaakt over de uitgangspunten en reikwijdte van het acquisitie-onderzoek;

3 de onderzoeksfase, waarin een diepgaande informatie-uitwisseling plaatsvindt, de wenselijkheid en de haalbaarherd van de overname nader bepaald worden en waarin de initiële waardebepaling plaatsvindt;

4 de onderhandelingsfase, waarin koper en verkoper overeenstemming over de prijs en andere verkoopvoorwaarden trachten te verkrijgen;

5 de 'due-diligence'-fase, waarin de koper de gelegenheid krijgt een verificatie-onderzoek bij de acquisitiekandidaat in te stellen. Dit onderzoek kan aanleiding geven tot wijzigingen in eerder gemaakte afspraken en mondt uit in het definitieve overnamecontract.

In elk van de hier genoemde fasen speelt de waardebepaling in meer of minder belangrijke mate een rol. Om die reden is getracht ook bij de case studies het overnameproces zoveel mogelijk te volgen. De nadruk lag daarbij op de onderzoeksfase en de onderhandelingsfase. In elk van de cases werd door de fusie- 
Tabel 1: Overzicht van waarderingsmethoden

\section{Methoden waarbij via discontering de contante waarde bepaald wordt}

\section{A 'Discounted cash flow'-methoden}

Er bestaan verschillende DCF-methoden. Bij de meest gebruikte methode wordt de 'free cash flow' gedisconteerd tegen de gewogen gemiddelde vermogenskostenvoet. Theoretisch gezien zouden de wegingscoëfficiënten in de vermogenskostenvoet gebaseerd moeten zijn op de marktwaarden van eigen en vreemd vermogen, maar bij ontstentenis van marktwaarden neemt men in de praktijk vaak toevlucht tot boekwaarden. Andere DCF-methoden zijn die waarbij dividenden gedisconteerd worden en die waarbij de kasstromen gedisconteerd worden die beschikbaar zijn voor uitkering aan aandeelhouders ('flow to equity method'). De verschillende DCF-methoden leiden niet zonder meer tot dezelfde uitkomsten. Zie voor nadere analyse, waarin ook de 'adjusted present value'-benadering betrokken wordt, Ross e.a. (1993, hoofdstuk 17).

\section{$B$ Methoden waarbij winsten gedisconteerd worden}

De meest gebruikte methode is de zogenaamde rentabiliteitsmethode, waarbij 'eeuwigdurend' constante winsten worden gedisconteerd. Bij de bepaling van deze winst, ook wel winstcapaciteit genoemd, staat de analyse en extrapolatie van de resultaten van de afgelopen jaren centraal. De in het verleden behaalde winsten worden 'genormaliseerd', bijvoorbeeld voor buitengewone baten en lasten, voor afschrijvingen en dotaties aan voorzieningen (Sman 1992, p. 92). Een andere methode is de zogenaamde goodwill-methode (zie bijvoorbeeld Van den Burg, 1989). Volgens deze methode wordt de waarde bepaald als de som van de intrinsieke waarde en de contante waarde van de overwinsten. De goodwill-methode is onder meer gebaseerd op de veronderstelling dat overrentabiliteit (en overwinst) van tijdelijke aard is. De redenering luidt dat overrentabiliteit is gebaseerd op concurrentievoordelen die gedoemd zijn te verdwijnen door de opkomst van concurrenten (Wytzes 1990, p. 408). Bi] de goodwill-methode staat de inschatting van het verloop van de overwinst centraal, i.c. het aantal jaren waarin nog overwinst aanwezig zal zijn en het verloop van de overwinst binnen die periode.

\section{De intrinsieke waarde, gebaseerd op het waardebegrip uit de financiële accounting}

Bij het gebruik van de intrinsieke waarde worden meestal correcties toegepast op het eigen vermogen zoals dat blijkt uit de balans van een onderneming (de zogenaamde 'zichtbare' intrinsieke waarde). Zo worden de activa meestal gewaardeerd tegen vervangingswaarde. Voor zover dat in de balans nog niet is geschied, worden de voorzieningen gewaardeerd tegen de contante waarde. Dit betreft bijvoorbeeld de voorziening voor belastinglatenties en de voorziening voor pensioenverplichtingen.

3 Methoden waarbij de waarde, met behulp van verhoudingsgetallen, ontleend wordt aan prijzen van vergelijkbare ondernemingen. Bijvoorbeeld:

- Koers/winst-verhouding

- Koers/omzet-verhouding

- Koers/dividend-verhouding

De prijzen kunnen ontleend zijn aan de beurswaarde van vergelijkbare ondernemingen of aan de prijzen die bij fusies of overnames van vergelijkbare ondernemingen to stand komen. In sommige gevallen wordt bij het gebruik van verhoudingsgetalien niet expliciet gerefereerd naar vergelijkbare ondernemingen, maar wordt gebruik gemaakt van vuistregels. Voor een illustratief overzicht van dergelijke, vaak industriespecifieke verhoudingsgetallen zij verwezen naar West (1992). 
en overname-adviseurs in de onderzoeksfase een waarderingsrapport opgesteld. Dit rapport speelt een belangrijke rol in de verdere besluitvorming, waaronder de onderhandelingen.

\section{De belangrijkste onderzoeksbevindingen}

De belangrijkste bevindingen van het onderzoek luiden als volgt:

1 In elk van de cases wordt gebruik gemaakt van verschillende waarderingsmethoden, zoals de DCF-methode (met verschillende scenario's), koers/winst-verhoudingen, koers/omzet-verhoudingen en de rentabiliteitsmethode. De uitkomsten van deze methoden bepalen in elk van de cases de bandbreedte op basis waarvan de partijen de onderhandelingen starten en waarbinnen de overeengekomen prijs valt. De DCF-methode speelt bij de waardebepaling niet de dominante rol die op grond van de financieel-economische literatuur verwacht zou kunnen worden.

2 De betrokkenen wijzen ter motivering van het geringe gewicht dat de DCF-methode in de waardebepaling krijgt zonder uitzondering op de informatie- en schattingsproblemen waarmee deze methode gepaard gaat, in het bijzonder ten aanzien van de bepaling van de kasstromen. Het overheersende beeld uit de case studies is dat waardering in hoge mate een informatie- en schattingsvraagstuk is. In alle cases staat de betrouwbaarheid van de prognoses ter discussie. In één van de cases komt de betrokken adviseur na een maandenlange verzameling en analyse van informatie tot de conclusie dat er in de prognoses nog steeds sprake is van 'koffiedikkijkerij'. In een andere case staat de interpretatie van een onverwachte omzetdaling in het afgelopen jaar ter discussie: is hier sprake van een trend of was de daling eenmalig? Van bijzonder belang is ook de informatie-achterstand van de koper ten opzichte van de verkoper. De koper heeft vaak beschikking over minder informatie dan de verkoper en kan niet onbevangen vertrouwen op de informatie en prognoses die hij van de verkoper krijgt. Dit blijkt bijvoorbeeld uit de case waarin een grondstoffenproducent wordt gekocht. De grondstoffenproducent heeft een bijzonder ingewikkelde groepsstructuur. De onderneming opereert bovendien in een markt die aan grote veranderingen onderhevig is. De adviseur die in opdracht van de koper van de grondstoffenproducent opereert, constateert dat de verkoper hem bij voortduring een veel rooskleuriger beeld van de onderneming en de markt voorspiegelt dan gerechtvaardigd is. Hij durft dan ook niet te vertrouwen op de prognoses die de grondstoffenproducent hem voorhoudt.

3 Uit de cases blijkt dat het gebruik van andere methoden dan de DCF-methode een uitweg biedt voor de schattingsproblemen van de DCF-methode. De betrokkenen motiveren het gebruik van deze methoden steeds met een verwijzing naar de problemen omtrent de DCFmethode.

4 In de cases wordt de keuze van de diverse waarderingsmethoden meestal niet anders gemotiveerd dan via een verwijzing naar hetgeen 'gebruikelijk' of 'normaal' is. De waarderingsmethoden worden in sterke mate als vuistregels gehanteerd. Etzioni (1987, p. 497) stelt ten aanzien van vuistregels: 'all these rules 'inform' the individual how best to behave, without any necessary calculations or forethought.'

Uiteraard maakt het vuistregelachtige karakter van de gehanteerde methoden het niet eenvoudig er een verklaring voor te vinden. Het is niet mogelijk veel verder te komen dan het verschaffen van mogelijke verklaringen. In de dissertatie wordt onderscheid gemaakt tussen twee typen verklaringen:

1 Verklaringen die berusten op een financieeleconomische optiek. Volgens deze verklaring kunnen de uitkomsten van de verschillende waarderingsmethoden worden opgevat als schattingen van de contante waarde.

2 Verklaringen die berusten op een analyse van de betekenis en functie van de waardebepaling in de betreffende cases. Deze verklaringen kunnen als aanvulling op de verklaringen onder 1 beschouwd worden. 


\section{Waarderingsmethoden als schattingen van de contante waarde}

Diverse auteurs wijzen op de superioriteit van de DCF-methode en de onjuistheid van andere in de praktijk gehanteerde methoden. Hoe kan het gebruik van koers/winst-verhoudingen, koers/omzet-verhoudingen en het gebruik van de goodwill-methode dan 'verdedigd' worden vanuit een financieel-economische conceptie? Waarom wordt niet alleen de DCF-methode gebruikt? Als we ons realiseren dat de DCF methode met grote schattingsproblemen gepaard gaat, kunnen we de andere methoden vanuit een andere optiek bezien dan gebruikelijk is bij de discussie over de juistheid en onjuistheid van methoden. Zo suggereert DeAngelo (1990) dat het gebruik van koers/ winst-verhoudingen van vergelijkbare genoteerde ondernemingen wellicht verklaard kan worden door het feit dat de prijs die op een efficiënte markt tot stand komt een betere schatting is van de waarde dan de uitkomst van de DCF-berekeningen die door een individu zijn uitgevoerd. Ook andere waarderingsmethoden kunnen op een dergelijke wijze 'gerationaliseerd' worden, dat wil zeggen verklaard worden vanuit een financieel-economische optiek. De bespreking in dit artikel blijft beperkt tot twee methoden: het gebruik van verhoudingsgetallen en de goodwill-methode. Eerst zal ik ingaan op de schattingsproblemen die zich voordoen bij toepassing van de DCFmethode.

\subsection{De DCF-methode en schattingsproblemen}

Kleine wijzigingen in de waarde van de parameters kunnen een grote invloed hebben op de uitkomst van de DCF-methode. Deze grote gevoeligheid impliceert dat kleine schattingsfouten in de parameters kunnen leiden tot grote fouten in de DCF-schatting. Fischel (1985) geeft een treffende verwoording van de implicaties van een dergelijke gevoeligheid:

'Indeed, anyone familiar with valuation techniques divorced from market transactions re- cognizes how uncertain, almost random, the whole process is: how slightly different estimates of future earnings or changes in the capitalization rate applied to such earnings can produce significantly different numbers; how different appraisers typically reach different conclusions.'

De grote gevoeligheid van waardeberekeningen voor schattingsfouten in de parameters wordt in de tabellen $2 \mathrm{a}$ en $2 \mathrm{~b}$ ge'll ustreerd voor schattingsfouten in de disconteringsvoet en de groeivoet van de omzet. Zo blijkt onder meer dat een daling van de disconteringsvoet met $1 \%$ tot een $21 \%$ hogere waarde leidt! Een verlaging van de omzetgroei met $1 \%$ resulteert in een waardedaling van $10 \%{ }^{4}$

De gevoeligheid van DCF-berekeningen voor schattingsfouten in de kasstromen illustreert dat de 'kwaliteit' van de voorspellingen van cruciaal belang is. Eén van de kenmerken van de kwaliteit is de betrouwbaarheid van voorspellingen. Betrouwbaarheid is hier gedefinieerd als de mate waarin de voorspellingen naar verwachting (bijvoorbeeld uitgedrukt in een waarschijnlijkheidsverdeling) uitkomen. Een kernprobleem is dat bij waarderingen de betrouwbaarheid van de voorspellingen niet te meten is. Bij repeterende voorspellingen als weersvoorspellingen en maandelijkse afzetschattingen, is een systematische analyse van voorspellingen en realisatie mogelijk. Dit is anders bij aandelenwaarderingen, waar het veelal gaat om eenmalige voorspellingen in een betrekkelijk 'verre' toekomst. Het feit dat de betrouwbaarheid van een voorspelling niet te meten is kan de bruikbaarheid van een voorspelling sterk verminderen. In een situatie van belangentegenstelling en informatie-asymmetrie tussen de koper en de verkoper van een onderneming staat bovendien de geloofwaardigheid van de prognoses van de verkoper ter discussie. Volgens DeAngelo (1990) kan het geringe gewicht dat de DCF-methode krijgt in door haar onderzochte management buy-outs verklaard worden door de geringe geloofwaardigheid van de prognoses van het management. De informatievoorsprong van het mana- 
Tabel 2: Gevoeligheid van DCF-berekeningen voor schattingsfouten

Tabel 2a: Basisscenario

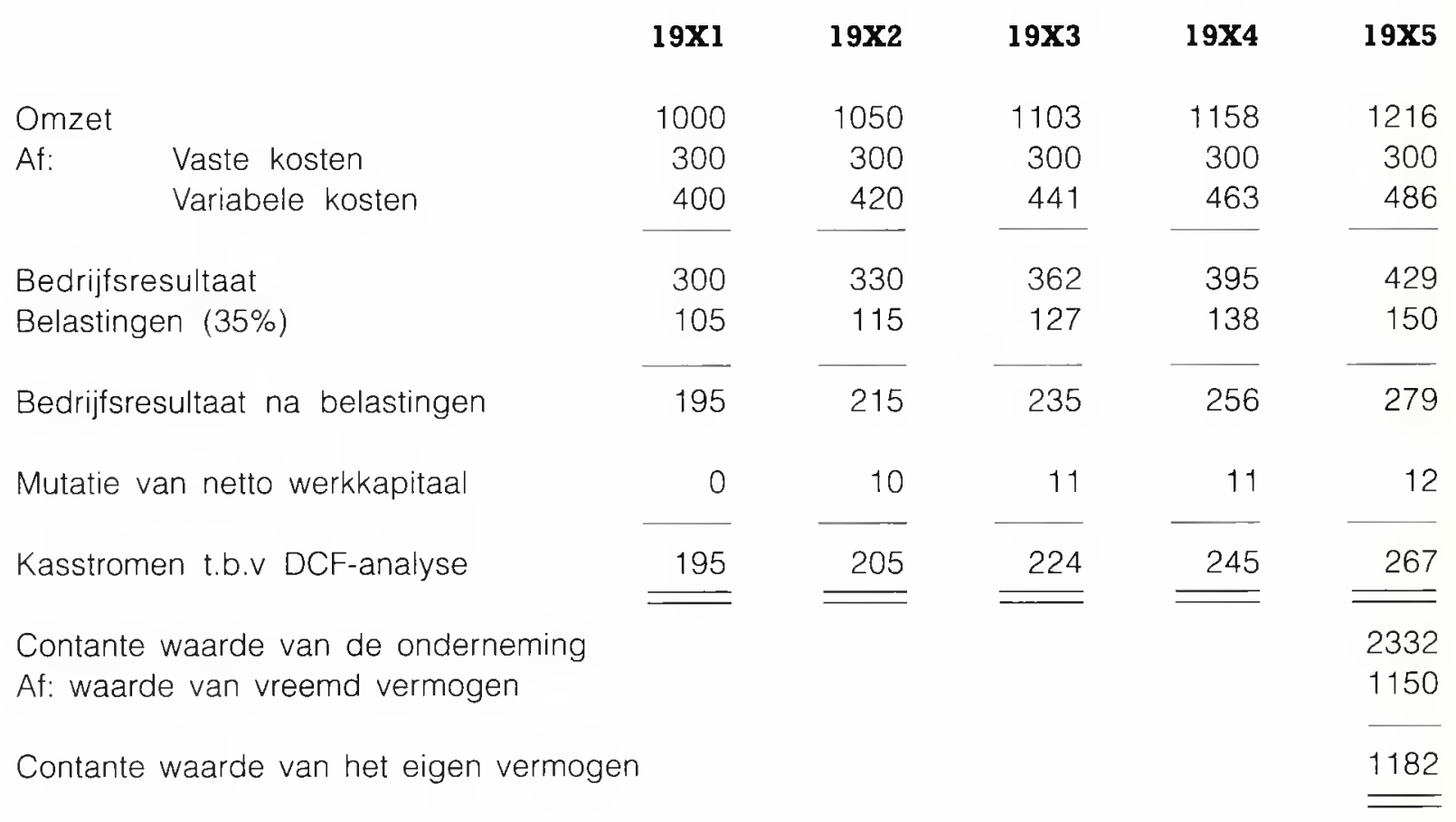

Veronderstellingen:

- de jaarlijkse omzetgroei gedurende de periode 19x2-19×5 bedraagt 5\%; na de planningshorizon (19X5) wordt de groei van de kasstromen nihil verondersteld. Uitgangspunt hierbij is het bedrijfsresultaat na belastingen in 19X5;

- gemakshalve is afgezien van afschrijvingen en investeringen in vaste activa;

- de (proportioneel) variabele kosten bedragen $40 \%$ van de omzet;

- het netto werkkapitaal bedraagt $20 \%$ van de omzet;

- de disconteringsvoet (de gewogen gemiddelde vermogenskostenvoet) bedraagt $11 \%$.

Tabel 2b: Gevoeligheid van de contante waarde van het eigen vermogen voor schattingsfouten in de groeivoet en de disconteringsvoet

$$
\text { disconteringsvoet }
$$

$0.10 \quad 0.11 \quad 0.12$

\begin{tabular}{lrrrrrrr}
\hline groeivoet omzet & 0.03 & 1169 & $(-0.01)$ & 949 & $(-0.20)$ & 766 & $(-0.35)$ \\
& 0.04 & 1298 & $(0.10)$ & 1064 & $(-0.10)$ & 869 & $(-0.26)$ \\
& 0.05 & 1431 & $(0.21)$ & 1182 & $(0.00)$ & 974 & $(-0.18)$ \\
& 0.06 & 1568 & $(0.33)$ & 1303 & $(0.10)$ & 1082 & $(-0.08)$ \\
& 0.07 & 1708 & $(0.45)$ & 1427 & $(0.21)$ & 1193 & $(0.01)$
\end{tabular}

De getallen tussen haakjes geven de relatieve afwijking weer ten opzichte van de waarde in het basisscenario. 
gement ten opzichte van de aandeelhouders en het belang dat zij heeft bij een lage waardering, maken de DCF-methode in die situatie minder geschikt.

Ook bij de bepaling van de disconteringsvoet is sprake van schattingsproblemen. Ter illustratie noem ik de schatting van de marktrisicopremie die in het Capital Asset Pricing Model (CAPM) wordt gehanteerd. De marktrisicopremie is het verschil tussen de verwachte (vereiste) rentabiliteit op de marktportefeuille en de risicovrije interestvoet. De marktrisicopremie is naar zijn aard een verwachting. Het probleem van verwachtingen is dat deze moeilijk te meten zijn. Men tracht dit te ondervangen door de schatting van de marktrisicopremie te baseren op gemiddelde historische waarden. De uitkomst blijkt echter zeer gevoelig te zijn voor de lengte van de periode die als uitgangspunt voor de schatting wordt genomen. Afhankelijk van de periode waarover de waarnemingen zijn gedaan varieert de marktrisicopremie in de Verenigde Staten van $4 \%$ tot $12 \%$ (zie Copeland e.a. 1990, p. 194 en Ross e.a. 1993, p. 269-270). Bovendien blijkt dat de marktrisicopremie niet constant is, maar varieert in de tijd, onder meer in samenhang met conjuncturele ontwikkelingen.

5.2 De koers/winst-verhouding en andere verhoudingsgetallen

In elk van de cases wordt gebruik gemaakt van waarderingsmethoden waarbij, via verhoudingsgetallen, zoals de koers/winst-verhouding en de koers/omzet-verhouding, de waarde van de onderneming wordt ontleend aan de marktprijs van vergelijkbare ter beurze genoteerde ondernemingen. Een mogelijke verklaring voor het gebruik van verhoudingsgetallen is dat de prijs die op een efficiënte markt tot stand komt een betere schatting is van de waarde dan de uitkomst van de DCF-berekeningen die door een individu zijn uitgevoerd. Op een efficiënte markt komt alle beschikbare, relevante informatie zonder vertraging en zonder vertekening in de prijs van de beleggingsobjecten tot uiting. Het verschijnsel marktefficiëntie kan begrepen worden door prijsvorming op te vatten als een proces van informatie-aggregatie. Voor een analytische uitwerking zij verwezen naar Diamond en Verrecchia (1981) en Verrechccia (1980, 1982). Intuïtief kan informatie-aggregatie als volgt aannemelijk worden gemaakt. Individuele beleggers beschikken elk over een deel van de totaal beschikbare informatie. Sommige beleggers beschikken over weinig informatie. Andere beleggers beschikken over veel informatie, bijvoorbeeld omdat ze beleggingsanalisten in dienst hebben. De beleggers nemen posities in op basis van de hen beschikbare informatie. Via vraag en aanbod wordt de informatie waarover de individuele beleggers beschikken geaggregeerd in de marktprijs. De marktprijs bevat dan de totaal beschikbare informatie en geen van de beleggers beschikt over meer informatie dan in de marktprijs besloten is. Op deze efficiënte markt doet de individuele belegger er goed aan les nr. 2 van Brealey \& Myers (1991, pp. 330-302) in acht te nemen: 'trust market prices'. Bij niet genoteerde ondernemingen ontbreekt een dergelijk aggregatieproces. De waardering geschiedt door individuen. Het is aannemelijk dat deze over minder informatie beschikken, c.q in staat zijn minder informatie te verwerken dan in een efficiënte markt het geval is. Door echter de waardering van een niet genoteerde onderneming te baseren op de marktprijs van vergelijkbare genoteerde ondernemingen, kan toch gebruik gemaakt worden van de 'informatierijke' marktprijzen.

Behalve het benutten van de informatie-aggregerende functie van de efficiënte markt zijn zijn er nog andere redenen voor het gebruik van verhoudingsgetallen van vergelijkbare beursfondsen aan te wijzen. Hiervoor wees ik reeds op de schattingsproblemen inzake de door aandeelhouders vereiste rentabiliteit. Door gebruik te maken van de marktprijs van vergelijkbare beursfondsen wordt - impliciet de vereiste rentabiliteit gelijk gesteld aan de 
rentabiliteitseis die de aandeelhouders van de vergelijkbare onderneming hanteren. Meer in het algemeen kan gesteld worden dat men zich bij het gebruik van marktprijzen tot op zekere hoogte immuniseert voor onjuistheden in het gehanteerde waarderingsmodel. In dit verband is het nuttig nog eens te wijzen op een inherente tekortkoming van de DCF-methode: het feit dat deze methode voorbij gaat aan zogenaamde reële opties.

Op deze verklaring voor het gebruik van verhoudingsgetallen kan op verschillende punten afgedongen worden. Zo kan gewezen worden op het feit dat aandelenkoersen geen 'inside'-informatie bevatten, terwijl degenen die betrokken zijn bij de waardering van niet genoteerde ondernemingen in sommige gevallen wel toegang tot 'inside-informatie' hebben. Een ander belangrijk probleem is uiteraard de beperkte vergelijkbaarheid van ondernemingen. Naarmate een genoteerde onderneming minder vergelijkbaar is met de te waarderen niet genoteerde onderneming is de marktprijs van de genoteerde onderneming minder bruikbaar, c.q. zijn aanpassingen voor verschillen noodzakelijk. Denk bijvoorbeeld aan verschillen in produktassortiment, afnemers, produktietechnologie en winstbepalingsstelsel hetgeen van belang is bij het gebruik van koers/ winst-verhoudingen. Met andere woorden: ook het gebruik van verhoudingsgetallen is met schattingsproblemen behept.

\subsection{De goodwill-methode}

Ook andere methoden kunnen verklaard worden als pogingen om de contante waarde te schatten. Het gebruik van de goodwill-methode vestigt de aandacht op het feit dat verschillen tussen de contante waarde en de intrinsieke waarde berusten op concurrentievoordelen. De relatie tussen de contante waarde, de intrinsieke waarde en de concurrentieverhoudingen is empirisch onderzocht aan de hand van de zogenaamde 'Tobin's q-ratio'. De q-ratio geeft de verhouding weer tussen de economische waarde (gemeten via de beurswaarde van de uitstaande vermogenstitels) en de vervangingswaarde van een onderneming. Uit onderzoek van Lindenberg en Ross (1981) blijkt dat ondernemingen in bedrijfstakken met betrekkelijk unieke produkten en unieke produktiefactoren die bijdragen tot monopolievorming, een relatief hoge q-ratio hebben. Ondernemingen in bedrijfstakken met een grote concurrentie en bedrijfstakken die onderhevig zijn aan stringente overheidsregulering hebben daarentegen een relatief lage q-ratio. Overigens blijkt uit het onderzoek van Lindenberg en Ross (1981) dat de bij de goodwillmethode gehanteerde veronderstelling van tijdelijke over- en onderrentabiliteit geen algemene wetmatigheid is. Veel bedrijfstakken worden gekenmerkt door langdurig hoge of langdurig lage q-ratio's (zie Lindenberg en Ross 1981, p. 26).

\subsection{Het simultane gebruik van verschillende waarderingsmethoden}

In elk van de cases worden verschillende methoden naast elkaar gebruikt. Elke waarderingsmethode is behept met schattingsproblemen. De DCF-methode is behept met schattingsproblemen ten aanzien van de kasstromen en de disconteringsvoet. Bij het gebruik van verhoudingsgetallen is de vergelijkbaarheid van ondernemingen een probleem. Het simultane gebruik van waarderingsmethoden kan geïnterpreteerd worden als een poging om de onvolmaakte waarde-schatting van de individuele waarderingsmethoden te 'poolen' teneinde tot een meer betrouwbare schatting van de contante waarde te komen dan op grond van een individuele methode mogelijk is. In de woorden van DeAngelo (1990, p. 101):

'The use of multiple, semi-independent valuation techniques avoids reliance on any one imperfect (potentially biased) approach.'

Wat is de status van de bovengenoemde verklaringen van het gebruik van verschillende waarderingsmethoden? Het feit dat de betrok- 


\section{MAB}

ken deskundigen de verschillende waarderingsmethoden als vuistregel hanteren hoeft in beginsel aan deze verklaring niet af te doen; er kan immers sprake zijn van 'thoughtless rationality' (zie Etzioni, 1987). Het feit dat in de cases bij het gebruik van koers/winst-verhoudingen soms ernstige twijfel bestaat over de vergelijkbaarheid van ondernemingen en deze verhoudingsgetallen niettemin toch gebruikt worden doet wel afbreuk aan deze verklaring.

De vraag naar de status van de bovengenoemde verklaring brengt ons in feite in aanraking met de discussie tussen voor- en tegenstanders van vuistregels. Voorstanders verdedigen vuistregels met behulp van een 'survival'-redenering. De regels berusten op de geaccumuleerde ervaring van vele generaties en zijn de uitkomst van een evolutionair proces waarin ze hun waarde bewezen hebben. Tegenstanders wijzen op het feit dat bij het gebruik van vuistregels voorbij gegaan wordt aan het feit dat elke beslissing en elke beslissingsomgeving uniek is. Zie voor de verschillende opvattingen bijvoorbeeld Etzioni (1987).

In het kader van mijn dissertatie heb ik de hierboven uitgewerkte verklaring aangeduid als een mogelijke verklaring die ons in staat stelt de in de praktijk gehanteerde waarderingsmethoden te begrijpen vanuit een financieel-economische conceptie. Uit de volgende paragraaf zal blijken dat een nadere analyse van de betekenis en functie van de waardebepaling in de praktijk meer licht werpt op het gebruik van de verschillende waarderingsmethoden.

\section{Waarderingsmethoden en de functie van de waardebepaling}

Het potentieel van case-onderzoek zou niet volledig benut worden als we bij de verklaring van waarderingsmethoden niet zouden trachten de waarderingsituatie te begrijpen en te interpreteren en enige afstand trachten te nemen van de financieel-economische concep- tie. De volgende uitspraak van Chua (1986, p. 618) inzake accounting-onderzoek kan ook van toepassing worden verklaard op het onderhavige onderzoek:

'There is much to be gained by moving accounting into the life-world of actors [...] It seeks the actor's definition of the situation and analyzes how this is woven into a wider social framework. This interpretative emphasis is valuable, for [...] we know how accounting numbers ought to function but have little knowledge of the meanings and roles they actually undertake.'

Een nadere analyse van de cases leert dat er niet zoiets is als 'de' waardebepaling. Hoewel dit in de cases niet erg expliciet geschiedt, is waardebepaling geen op zich staande activiteit. De waardebepaling blijkt verschillende functies te vervullen. Deze functies worden in sterke mate bepaald door de rol die de fusieen overname-adviseur vervult: het geven van ondersteuning bij de koop en verkoop van ondernemingen. Uit de cases komen de volgende functies van de waardebepaling en van waarderingsmethoden aan de orde:

1 Het schatten van de verwachte of haalbare verkoop- of koopprijs;

2 Ondersteuning bij de beslissing tot koop of verkoop van de onderneming;

3 Ondersteuning bij onderhandelingen;

4 Waardebepaling dient als voertuig om overeenstemming te bereiken tussen koper en verkoper;

5 Waardebepaling dient als middel om de gerealiseerde prijs te verantwoorden.

6.1 Het schatten van de verwachte of haalbare verkoop- of koopprijs

In de cases waarbij een adviesbureau en een metaalbedrijf verkocht worden, wordt op basis van de uitkomst van de verschillende waarderingsmethoden een indicatie gegeven van de verwachte verkoopprijs en wordt ook een advies gegeven omtrent de minimaal te accepteren prijs. Bij het metaalbedrijf speelt de analyse van de potentiële kopers en de prijs 


\section{MAB}

die deze voor eventuele synergievoordelen zouden willen betalen een centrale rol. Er worden verwachte verkoopprijzen voor verschillende typen kopers geschat. Gegeven het doel van de waardebepaling, het schatten van de prijs, ligt het voor de hand waarderingsmethoden te gebruiken die potentiële kopers en verkopers ook gebruiken, ook al zou de betrokkene zelf een fervent voorstander zijn van de DCF-methode. In het waarderingsrapport van het metaalbedrijf benadrukt de betreffende adviseur dat waarderingsmethoden gebruikt zijn die door potentiële kopers gebruikt kunnen worden.

In een ander geval stelt de adviseur ten aanzien van een 'primitieve' waarderingsmethode dat deze volgens hem niet juist is, maar dat hij de methode toch gebruikt omdat degene met wie hij onderhandelt deze methode gebruikt.

\subsection{Ondersteuning bij de beslissing tot koop of verkoop}

Het betreft hier in het bijzonder de beslissing al dan niet door te gaan met de voorgenomen koop of verkoop gegeven de verwachte (ver)koopprijs. In feite vergelijkt de koper of verkoper van een onderneming de value in use', de waarde die hijzelf aan de onderneming toekent, met de 'value in exchange', de prijs die een koper biedt of de prijs die een verkoper vraagt. Bij de case waarin een metaalbedrijf verkocht wordt valt de prijs die kopers bieden (de 'value in exchange') nogal tegen en de aandeelhouders besluiten aanvankelijk de aandelen niet te verkopen. Met het oog op dreigende opvolgingsproblemen gaan ze later echter alsnog akkoord: de 'value in use' is nog lager dan de 'value in exchange'.

\subsection{Ondersteuning bij onderhandelingen}

De waarderingsmethoden krijgen dan het karakter van argumenten om de andere partij te overtuigen teneinde de gewenste prijs te bereiken. Zo zegt een consultant, die tevreden is over de verkoop van een adviesbureau aan een participatiemaatschappij: 'Het feit dat ik verschillende waarderingsmethoden heb gebruikt die alle ongeveer dezelfde bandbreedte opleverden was erg nuttig. Het gaf mij verschillende argumenten om de participatiemaatschappij te overtuigen.' Zie in dit verband ook de redenering van Gregory (1992, pp. 99100) waarbij hij pleit voor het gebruik van koers/winst-verhoudingen, nadat hij eerder heeft gewezen op de grote beperkingen van deze methode:

'None the less, there is some good news for keen supporters of the earnings-based approach [koers/winst-verhoudingen, W.H.] because many market participants use an earnings-based valuation methodology. In the case of valuation prepared for the sale or purchase of a business it is a useful and necessary negotiating tactic to have prepared such a valuation irrespective of any views one may have of its validity.'

\subsection{Waarderingsmethoden als voertuig om overeenstemming te bereiken}

Een belangrijk inzicht in dit verband is dat in elk van de cases de koper en de verkoper in meer of mindere mate 'op elkaar zijn aangewezen' in die zin dat de andere partij de meest gerede partij is om zaken mee te doen. Ik zal dit illustreren aan de hand van de case waarbij een grondstoffenproducent wordt gekocht. De partijen zijn al lange tijd met elkaar in onderhandeling, maar verschillen met elkaar over de hoogte van de prijs. De vraagprijs is ruim $100 \%$ hoger dan de biedprijs. Het verschil is terug te voeren op een verschil in toekomstvisie, met name de ontwikkeling van de markt. De toekomstige ontwikkelingen en de prognoses van kasstromen zijn onderwerp van voortdurende discussies en onderhandelingen. Tegelijkertijd leeft het besef dat de partijen op elkaar zijn aangewezen. Er bestaat tussen de partijen een belangrijke leverancier/afnemer relatie. Voor de koper heeft de grondstoffenproducent belangrijke strategische waarde. Voor de grondstoffenproducent is de andere 
partij de meest gerede koper. Teneinde de ontstane impasse te doorbreken besluiten de partijen de rentabiliteitsmethode als uitgangspunt te nemen voor de waardebepaling. Op grond van deze methoden bereiken ze uiteindelijk overeenstemming over de prijs. Dat wordt mogelijk door het feit dat de discussie voor toekomstige ontwikkelingen plaats maakt voor een analyse van de verlies- en winstrekeningen van de afgelopen jaren. Het 'normaliseren' van de resultaten geeft aanzienlijk minder aanleiding tot discussie dan het bepalen van toekomstige kasstromen. Het vermogen van waarderingsmethoden om bij te dragen tot het bereiken van overeenstemming wordt in de dissertatie aangeduid als de communicatiefunctie van deze methoden. Behalve door de rentabiliteitsmethode wordt deze functie in de cases met name vervuld door de koers/winstverhoudingen. Belangentegenstelling en informatie-asymmetrie kunnen ertoe leiden dat partijen heel verschillend tegen de toekomst aankijken of althans doen blijken heel anders tegen de toekomst aan te kijken. Het gebruik van koers/winst-verhoudingen beperkt de ruimte voor meningsverschillen en discussie. De communicatiefunctie van bijvoorbeeld de rentabiliteitsmethode en koers/winst-verhoudingen is terug te voeren op het geringe aantal parameters dat voorwerp van discussie kan zijn (in vergelijking met de DCF-methode) en het (schijnbaar) objectieve karakter van de methoden. Zo wordt bij koers/winst-verhoudingen gebruik gemaakt van geverifieerde winstcijfers en waarneembare marktprijzen. Het belang van objectiviteit komt in de dissertatie ook nadrukkelijk naar voren in de cases waarin aandelen worden gewaardeerd onder de werking van de blokkeringsregeling. In de onderhavige cases vervullen de deskundigen (i.c. accountants) de rol van arbiter en bemiddelaar. De accountant in een van de cases wijst het gebruik van de DCF-methode af omdat deze gebaseerd is op subjectieve voorspellingen die een bron van meningsverschil tussen de betrokken partijen zouden kunnen vormen. Ten behoeve van de gewenste objectiviteit maakt de accountant bij de waardering gebruik van de rentabiliteitsmethode, louter gebaseerd op historische ciffers, en op de intrinsieke waarde.

\subsection{Waardebepaling als middel om verantwoor- ding af te leggen over de prijs}

Dit aspect komt duidelijk naar voren in de case waarin een adviesbureau wordt verkocht aan een participatiemaatschappij. De betrokken medewerker van de participatiemaatschappij gebruikt bij de waardebepaling onder meer de DCF-methode en koers/winst-verhoudingen. Hij concludeert dat de uitkomst van de DCFmethode 'veel te hoog' is en baseert de waardebepaling grotendeels op koers/winst-verhoudingen. Het oordeel dat de uitkomst van de DCF-methode te hoog is, blijkt mede gebaseerd te zijn op het feit dat hij achteraf beoordeeld wordt op het uitkomen van de prognoses. Zo stelt hij enige tijd na het tot stand komen van de transactie: $\mathrm{Na}$ de acquisitie dreigt de winst achter te blijven, daar word ik nu op aangesproken'. Het zal duidelijk zijn dat bij het gebruik van waarderingsmethoden waarbij geen expliciete uitspraken omtrent de toekomst worden gedaan, zoals koers/winstverhoudingen, de kwetsbaarheid van de betrokkenen in dit opzicht geringer is. In dit verband is ook de volgende constatering interessant. Geistauts en Eisenbach (1987) stellen in een vergelijking van voorspelmethoden dat managers die gebruik maken van subjectieve voorspellingen zich aan grotere persoonlijke risico's blootstellen dan degenen die objectieve methoden gebruiken. Objectieve (statistische) methoden zijn gebaseerd op gekwantificeerde gegevens en volgen een specifieke procedure. De gevolgde procedure is te repliceren en te controleren. De stappen die gevolgd worden in een subjectieve methode zijn moeilijker te beschrijven, te repliceren en dus ook moeilijker te verdedigen. Met dit inzicht kan ook het gebruik van verhoudingsgetallen en de rentabiliteitsmethode beredeneerd worden. Bij deze methoden worden geen voorspellingen gedaan die achteraf onjuist kunnen blijken te zijn; er wordt daarentegen gebruik 
gemaakt van geverifieerde en (schijnbaar) objectieve informatie.

\section{Besluit}

In de financieringsliteratuur worden waarderingsmethoden vooral beoordeeld op hun 'technische' juistheid. Op grond van dit criterium worden sommige methoden als juist en andere methoden als minder juist of onjuist beoordeeld. Het in dit artikel gepresenteerde case-onderzoek werpt een ander licht op de waarderingsmethoden. Het besef dat informatie- en schattingsproblemen de kern van het waarderingsvraagstuk vormen, geeft het vraagstuk van de keuze van de verschillende waarderingsmethoden een andere dimensie. Het exclusieve gebruik van de DCF-methode is dan, ook vanuit een financieel-economisch oogpunt, niet langer vanzelfsprekend en andere waarderingsmethoden kunnen dan eveneens vanuit een financieel-economische optiek begrepen worden. De cases laten daarenboven de rol van waarderingsmethoden in het kader van de besluitvorming zien. Gegeven het vaak arbitraire karakter van de waardebepaling is het begrijpelijk dat vuistregels en objectiviteit zo'n belangrijke rol spelen. Vuistregels vervullen een belangrijke communicatiefunctie: ze dragen ertoe bij dat transacties op een soepele wijze tot stand komen. Naar mijn mening onderstreept het onderhavige onderzoek het door verschillende auteurs benadrukte belang van case-onderzoek in de financiering. Het werpt nieuw licht op zaken die in theorie al met een zeker vooroordeel zijn afgedaan. Het onderzoek heeft volgens mij ook betekenis voor de praktijk, i.c. voor fusie- en overname-adviseurs. Uit de cases blijkt dat de waardebepaling in feite verschillende activiteiten omvat en verschillende functies vervult. Maar dit geschiedt allemaal op een zeer impliciete wijze. De praktijk zou er goed aan doen ten behoeve van zichzelf en hun cliënten deze activiteiten en functies nader te expliciteren teneinde het produkt 'waardebepaling' beter te definiëren

\section{Literatuur}

Aardema. E., 1991. Waardering van Incourante Aandelen voor de Belastingheffing. Deventer, FED

Baumol, W.J. en R.E. Quandt, 1964, 'Rules of Thumb and Optimally Imperfect Decisions', The American Econo mic Review, vol. 54 (maart), pp. 23-46.

Bouma, J.L., 1980, Leerboek der Bedrifseconomie, deel II Wassenaar, Delwel.

Brealey. R.A. en S.C. Myers, 1991. Principles of Corporate Finance, New York, McGraw-Hill.

Burg. M.H.J. van den, 1989, 'Financiële Evaluatie bij Overnames', Tijdschrift Financieel Management, jrg 9 (januari-februari), pp. 6-19.

Chua. W.F., 1986. 'Radical Developments in Accounting Thought', The Accounting Review, vol. 61 (oktober), pp $601-632$

Copeland, T.E., T. Koller en J. Murrin. 1990, Valuation. New York, John Wiley.

DeAngelo, L.E.. 1990, 'Equity Valuation and Corporate Control', The Accounting Review, vol. 65 (januari), pp. 93-112

Diamond, D.W. en R.E. Verrecchia. 1981, 'Information Aggregation in a Noisy Rational Expectations Economy', Journal of Financial Economics, vol. 9 (maart), pp. 221-235.

Etzioni. A.. 1987. 'On Thoughtless Rationality (Rules of Thumb)', Kyklos, vol. 40 (nr.4), pp. 496-514

Fischel, D.R., 1985. 'The Business Judgment Rule and the Trans Union Case', The Business Lawyer, vol. 40 (augustus), pp. 1437-1455

Geistauts, G.A. en T.G. Eischenbach, 1987. 'Bridging the Gap Between Forecasting and Action', in: Wright, G. en P. Ayton (eds.), Judgmental Forecasting. New York. John Wiley, pp 177-195.

Gregory, A., 1992, Valuing Companies. New York, Woodhead-Faulkner.

Herter, H.M., L.W.G. Lammers en R.M. Pit, 1992, 'Financiële Evaluatie van Acquisities: Aquisitieproces', in: Traas, $L$. en $E$. de With (red.). Handboek Management Accounting. Alphen aan den Rijn, Samsom. C1800: pp. 1-11.

Holterman, W.G.M., 1993, De waardering van niet genoteerde aandelen, theorie en cases, dissertatie, Rijksuniversiteit Groningen.

Lindenberg. E.B. en S.A. Ross, 1981, 'Tobin's q Ratio and Industrial Organization;. The Journal of Business, vol. 54 (januari), pp. 1-32

Rappaport. A., 1986. Creating Shareholder Value, New York. Free Press.

Sman, R., 1992, Met Waardering.... Deventer, Kluwer

Van Dale, 1992, Groot Woordenboek der Nederlandse Taal, Utrecht, Van Dale Lexicografie

Verrecchia, R E., 1980. 'Consensus Beliefs, Information Acquisition, and Market Information Efficiency'. The American Economic Review, vol. 70 (december), pp. 874-884

Verrecchia. R.E, 1982. 'Information Acquisition in a Noisy Rational Expectations Economy'. Econometrica, vol. 50 (november), pp. 1415-1430.

West, T.L., 1992, 'Rules of Thumb', in: West, T.L en J.D Jones (eds.), Handbook of Business Valuation. New York, John Wiley, pp. 113-127 


\section{MAB}

Wytzes, H.C., 1990, Ondernemingsfinanciering, Leiden, Stenfert Kroese.

\section{Noten}

1 Voor een meer verfijnde classificatie en een vollediger overzicht en beschrijving van waarderingsmethoden zij verwezen naar Holterman (1993, pp. 211-228).

2 De lezer zij gewaarschuwd dat diverse waarderingsmethoden in de praktijk met verschillende benamingen worden aangeduid. Ook bestaan er voor diverse waarderingsmethoden terminologische verschillen tussen enkele gangbare Nederlandstalige financieringsleerboeken en de praktijk. Ter illustratie worden hier de begrippen rentabiliteitswaarde en rendementswaarde genoemd. In de literatuur (zie bijvoorbeeld Bouma 1980, p. 270 en 355) zijn deze begrippen synoniemen en worden gehanteerd in de algemene betekenis van contante waarde van toekomstige kasstromen. In de praktijk wordt het begrip gebruikt om de uitkomst van de rentabiliteitsmethode (zie tabel 1) aan te duiden. Het begrip rendementswaarde wordt gebruikt voor een bijzondere vorm van dividend-discontering welke gebruikt wordt om minderheidsbelangen te disconteren (zie bijvoorbeeld Aardema 1991). Voor een vollediger bespreking van de terminologische verwarring inzake waarderingsmethoden zij verwezen naar Holterman (1993, pp. 211-228)

$3 \mathrm{Er}$ bestaan diverse andere indelingen van de fasen van het acquisitieproces, zie bijvoorbeeld Copeland e.a. (1990 pp. 323-341) en Herter e.a (1992). Het onderscheid tussen de indelingen berusten meestal op verschil in de mate van detaillering en op terminologische verschillen.

4 Uiteraard betreft het hier willekeurig cijfervoorbeeld. De mate van gevoeligheid varieert van geval tot geval en blijkt afhankelijk te zijn van het patroon van de kasstromen en de hoogte van de disconteringsvoet (zie Holterman 1993. hoofdstuk 4). 